\title{
Anti-helminthic Activity of Consolida orientalis (Gay) Schröd. on Caenorhabditis elegans Nematodes and Determination of Possible Active Ingredients
}

\author{
Hulya Ozpinar ${ }^{1, a, *}$ \\ ${ }^{1}$ Department of Pharmaceutical Botany, Faculty of Pharmacy, Sivas Cumhuriyet University, 58140 Sivas, Turkey
} *Corresponding author

A R T I C L E IN F O A B S T R A C T

Research Article

Received : 07/07/2021

Accepted : 13/07/2021

\begin{abstract}
Helminthiasis is an important parasitic disease, many of which are zoonotic, particularly common in developing countries and, in countries with hot and humid climates. Intestinal parasites can cause significant manifestations at all levels of the gastrointestinal tract, as well as anemia and growth retardation. This study aims to demonstrate the anti-helminthic effect of Consolida orientalis on Caenorhabditis elegans, which is a helminth model, and introduce new chemotherapeutic candidate substances with anti-helminthic effect to the literature by identifying possible active ingredients with GC-MS analysis. In our study, flower, leaf, stem and aerial part plant extracts of Consolida orientalis were used at $40 \mathrm{mg} / \mathrm{mL}, 20 \mathrm{mg} / \mathrm{mL}, 10 \mathrm{mg} / \mathrm{mL}, 5 \mathrm{mg} / \mathrm{mL}, 2.5 \mathrm{mg} / \mathrm{mL}, 1.25 \mathrm{mg} / \mathrm{mL}$ concentrations. In addition, possible active ingredients found in plant extracts were determined by GC-MS analysis. As a result of the study, it was determined that the aerial part, leaf and stem extract of the first four concentrates $(40 \mathrm{mg} / \mathrm{mL}, 20 \mathrm{mg} / \mathrm{mL}, 10 \mathrm{mg} / \mathrm{mL}, 5 \mathrm{mg} / \mathrm{mL})$ of Consolida orientalis were more effective than pyrantel pamoate at a concentration of $5 \mathrm{mg} / \mathrm{mL}$. According to our study findings, chemotherapeutics such as Dihidrocarvone and $2(3 \mathrm{H})$-Benzoxazolone with new antihelmintic-antiparasitic activity are thought to contribute to further research.
\end{abstract}

Anti-helminthic activity Caenorhabditis elegans Consolida orientalis Dihidrocarvone 2(3H)-Benzoxazolone

(iD)https://orcid.org/0000-0001-8154-0874|

hulya1177@yahoo.com.tr

This work is licensed under Creative Commons Attribution 4.0 International License

\section{Introduction}

Helminthiasis is an important parasitic disease, many of which are zoonotic, particularly common in developing countries and, in countries with hot and humid climates. Although not as much as in tropical countries, helminthiasis is significantly more frequent in some settlements of Turkey due to lack of infrastructure and lack of education. Intestinal parasitoses can cause significant manifestations at all levels of the gastrointestinal tract, as well as anemia and growth retardation. Cholecystitis, cholangitis, liver abscess, pancreatitis, ileus, and acute appendicitis are important complications (Gul and Nazligul, 2008). In addition, helminth infections are one of the most important causes of physical growth and intellectual growth retardation (Bethony et al., 2006). Studies have shown that helminth infections have the negative impact on the school performance of infected children and the future of the country (Drake and Bundy, 2001). In addition, it has been reported that these infections may have a detrimental effect on cognition and educational achievement (Drake and Bundy, 2001; Gatti et al., 2000; Tappeh et al., 2010). As a result, people's uncontrolled use of anthelmintic drugs has been one of the reasons for the development of resistance (Kaminsky et al., 2008; Smout et al., 2010). As with many diseases developing resistance to the drug of parasites, causes parasitic diseases to be a public health problem and causes difficulties in the treatment (Kaminsky et al., 2008; Smout et al., 2010).

In recent years, the use of herbal medicines has been increasing day by day. Many herbs are used for therapeutic purposes in various diseases and effects are seen like synthetic drugs. Especially in the eradication of pathogens that develop resistance to drugs, products derived from plants, it has been used as a traditional method of treatment since ancient times (Ozpinar, 2020).

Ranunculaceae family, of which Consolida orientalis (Gay) Schröd. (C. orientalis) is a member, includes 59 genera and approximately 2500 species in the world, and 18 genera and 216 species in Turkey (Ozcelik and Korkmazturk, 2013). Consolida genus, which is one of the quite common breeds of this family, highly adapted to the dry climate. It can grow on steppes, deserts and even drystoned slopes. This genus is spreading around the world in Southern Europe, North Africa, West Asia, and Anatolia (Yin et al., 2020). C. orientalis, popularly known as 
"Purple Flower" in Turkey, has natural spread in southern Europe, Turkey, and North Africa. It is an annual herbaceous plant with dark purple flowers from May to August. They can be considered weeds, as they intensively invade cultivated fields. These plants are attractive to bees, birds and butterflies and can be used as ornamental plants (Ozpinar, 2020). In the literature, anti-acaricide effects of C. orientalis on some types of ticks (Ghanbarpour et al., 2019; Tavassoli et al., 2012), and anti-protozoal effects on Leishmania spp. (Marin et al., 2009) and Trypanosoma cruzii (Marín et al., 2017) were mentioned, but no studies were found except for ethnobotanical studies on the antihelminthic effects of this species.

Caenorhabditis elegans ( $C$. elegans), Class: Chromadorea, Order: Rhabditida, Family: Rhabditidae, Genus: Caenorhabditis, Species: Caenorhabditis elegans is a nematode also called threadworm (Figure 1). $C$. elegans can be a good antihelmintic model, studies have been reported (Asha et al., 2001; Ibrahim, 1992; Mathew et al., 2016; Ozpinar, 2020).

This study was aims to demonstrate the anti-helminthic effect of $C$. orientalis on $C$. elegans, which is a helminth model, and introduce new chemotherapeutic candidate substances with anti-helminthic effect to the literature by identifying possible active ingredients with GC-MS analysis.

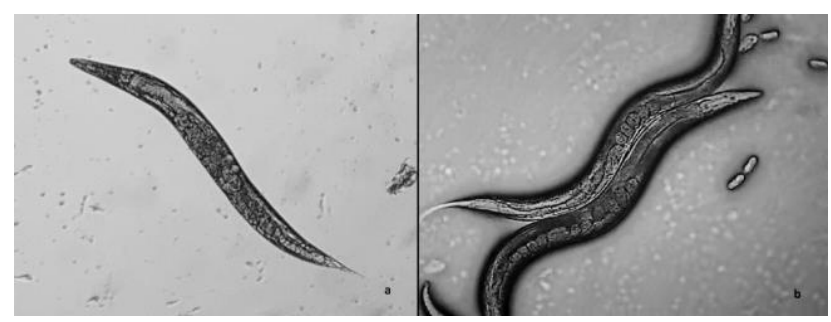

Figure 1. C. elegans appearance under a stereo microscope (a; dead nematode, $b$; living nematode)

\section{Materials and Methods}

\section{Plant Material}

C. orientalis was collected from an area in Sivas Central district in July 2019 with an altitude of $1250 \mathrm{~m}$ at the coordinates of $39^{\circ} 42^{\prime} 11^{\prime \prime} \mathrm{K}, 37^{\circ} 0^{\prime} 56^{\prime \prime} \mathrm{D}$.

Species determination of the collected samples was done by Asst. Prof. Hulya Ozpinar, who is faculty member in Sivas Cumhuriyet University Faculty of Pharmacy, Department of Pharmaceutical Botany.

\section{Preparation of Plant Extracts}

In our study, flowers, leaves, stems, and aerial part extracts of $C$. orientalis were used. The samples were first washed with tap water and then pure water, then dried on drying paper. Plant samples were individually grounded in the grinder and homogenate was prepared. $100 \mathrm{~g}$ of this homogenate were taken and $300 \mathrm{~mL}$ of ethanol was added on top. It was kept at room temperature in the shaker for 24 $\mathrm{h}$ at $150 \mathrm{rpm}$. At the end of that time, the material was filtered twice with Whatman paper No:1. Ethanol in the resulting liquid part was completely evaporated in the evaporator (Buchi R-100 equipped with Vacuum Pump V300 and Control unit I-300).

\section{GC-MS Analysis}

For GC-MS, the HP-5 MS IU capillary column (30 m X $250 \mu \mathrm{m}$ X $0.25 \mu \mathrm{m}$ ) and the 7890A (Agilent) model GCMS device with 5975C (Agilent) inert MSD mass detector were used. In GC-MS, an electron ionization system with $70 \mathrm{eV}$ ionization energy and Helium (He) was used as carrier gas with $99.999 \%$ purity. The carrier gas entered the He column with a flow rate of $1.5 \mathrm{~mL} / \mathrm{min}$ and a starting pressure of 17,897 psi. After keeping the oven temperature at the starting temperature of $50^{\circ} \mathrm{C}$ for 2 minutes, the rate of temperature rise in all stages was $5^{\circ} \mathrm{C} / \mathrm{min}$ and was increased to $80^{\circ} \mathrm{C}$ (waiting 2 minutes at this temperature), $100^{\circ} \mathrm{C}$ (waiting 1 minute at this temperature), $150^{\circ} \mathrm{C}$ (waiting 1 minute at this temperature), $240^{\circ} \mathrm{C}$ (waiting 1 minute at this temperature) and $270^{\circ} \mathrm{C}$ (waiting 7 minutes at this temperature) respectively.

The GC-MS analysis was performed by the Giresun University Central Research Laboratory Application and Research Centre, Giresun, Turkey.

\section{Anti-helminthic Activity}

Obtaining C. elegans Strains

The strain of wild type $C$. elegans N2 was purchased from the Ceanorhabditis Genetic Center (University of Minnesota, Minneapolis, USA).

Synchronization of C. elegans nematodes

About 20 adult $C$. elegans were transferred to the Nematot Growth Media (NGM) petri dish containing Escherichia coli OP50 (E. coli OP50). After laying for 4-6 hours, adult $C$. elegans were removed from the petri dish. These eggs formed synchronized offspring. These were used in the study when it came to adult form at the end of the 3 rd day. This procedure was carried out with 5 petri at the same time in order to provide sufficient nematodes for the study.

\section{Preparation of Nematode Growth Media}

A $2.5 \mathrm{~g}$ peptone, $3 \mathrm{~g} \mathrm{NaCl}$, and $20 \mathrm{~g}$ agar were dissolved in $1 \mathrm{~L}$ of distilled water. After autoclaving at $125^{\circ} \mathrm{C}$ for 15 min, the mixture was cooled to $55^{\circ} \mathrm{C}$. Homogenization was obtained by adding $1 \mathrm{~mL} \mathrm{MgSO} 4$ (1M), $1 \mathrm{~mL}$ cholesterol (5 mg/mL), $1 \mathrm{~mL} \mathrm{CaCl} 2$ (1M), $25 \mathrm{~mL} \mathrm{KH}_{2} \mathrm{PO}_{4}$ buffer ( $\mathrm{pH}$ 6 ), which had been previously prepared and filtered through a $0.2 \mu \mathrm{m}$ mesh, to the medium. C. orientalis' flower, leaf, stem and aerial part plant extracts were added to NGM separately, with final concentrations of $40 \mathrm{mg} / \mathrm{mL}$, $20 \mathrm{mg} / \mathrm{mL}, 10 \mathrm{mg} / \mathrm{mL}, 5 \mathrm{mg} / \mathrm{mL}, 2.5 \mathrm{mg} / \mathrm{mL}, 1.25 \mathrm{mg} / \mathrm{mL}$ and experiment groups were formed. In addition, $10 \mathrm{~mL}$ was taken from Kontil $(250 \mathrm{mg} / 5 \mathrm{~mL})$, which is used as an anthelmintic drug and whose active ingredient is pyrantel pamoate and dissolved within $100 \mathrm{~mL} \mathrm{NGM}$ and prepared in a concentration of $5 \mathrm{mg} / \mathrm{mL}$. It formed this positive control group. The negative control group was created only from NGM. NGM was transferred $10 \mathrm{~mL}$ each to petri dish and, the prepared E. coli OP50 strain was added to NGM.

\section{Determination of Anthelmintic Activity}

In order to determine the anthelminthic effect of plant extracts on $C$. elegans, 20 synchronized adult $C$. elegans were transferred to NGMs containing plant extracts and $E$. coli OP50. The number of live and dead nematodes was recorded under a stereo microscope every day for 21 days. Each concentration was studied with 5 petri dishes, and the 
work was repeated 2 times. Nematodes who had completely lost their pharynx pumping movements were considered dead.

\section{Statistical Analysis}

The data obtained in our study were evaluated in the SPSS (Ver: 22.0) program and the One Way Anova and Tukey test was used, the level of error was taken as 0.05.

\section{Results}

In our study, in the sample of aerial part, it was observed that all nematodes died at the end of the 2nd day at a dose of $40 \mathrm{mg} / \mathrm{mL}$, at the end of the 3rd day at a dose of $20 \mathrm{mg} / \mathrm{mL}$, and at the end of the 4th day at the dose of $10 \mathrm{mg} / \mathrm{mL}$. All nematodes died at the end of the 13th day at a dose of $5 \mathrm{mg} / \mathrm{mL}$, at the end of the 19th day at a dose of $2.5 \mathrm{mg} / \mathrm{mL}$, at the end of the $1.25 \mathrm{mg} / \mathrm{mL}$ dose and at the end of the 20th day in the negative control group (Figure 2 ). When these data were compared with the control group, the difference between the negative control group and doses of $40 \mathrm{mg} / \mathrm{mL}, 20 \mathrm{mg} / \mathrm{mL}, 10 \mathrm{mg} / \mathrm{mL}, 5 \mathrm{mg} / \mathrm{mL}$ was found to be statistically significant $(\mathrm{P}<0.05)$. In addition, the difference between doses of $2.5 \mathrm{mg} / \mathrm{mL}, 1.25 \mathrm{mg} / \mathrm{mL}$ with a dose of $40 \mathrm{mg} / \mathrm{mL}, 20 \mathrm{mg} / \mathrm{mL}$ and, likewise, with doses of $10 \mathrm{mg} / \mathrm{mL}$; difference between doses of $5 \mathrm{mg} / \mathrm{mL}$, $2.5 \mathrm{mg} / \mathrm{mL}, 1.25 \mathrm{mg} / \mathrm{mL}, 40 \mathrm{mg} / \mathrm{mL}$ with a dose of 5 $\mathrm{mg} / \mathrm{mL}, 20 \mathrm{mg} / \mathrm{mL}, 10 \mathrm{mg} / \mathrm{mL}, 1.25 \mathrm{mg} / \mathrm{mL}$ doses. The difference between doses of $40 \mathrm{mg} / \mathrm{mL}, 20 \mathrm{mg} / \mathrm{mL}, 10$ $\mathrm{mg} / \mathrm{mL}$ with a dose of $2.5 \mathrm{mg} / \mathrm{mL}, 40 \mathrm{mg} / \mathrm{mL}$ with a dose of $1.25 \mathrm{mg} / \mathrm{mL}, 20 \mathrm{mg} / \mathrm{mL}, 10 \mathrm{mg} / \mathrm{mL}, 5 \mathrm{mg} / \mathrm{mL}$ was found to be statistically significant $(\mathrm{P}<0.05)$.

When the leaf extract is examined, it was observed that all nematodes were died at the end of the 9th day at a dose of $40 \mathrm{mg} / \mathrm{mL}$, at the end of the 12th day at a dose of 20 $\mathrm{mg} / \mathrm{mL}$, and at the end of the 14th day at a dose of 10 $\mathrm{mg} / \mathrm{mL}$. At the end of the $17 \mathrm{th}$ day at a dose of $5 \mathrm{mg} / \mathrm{mL}$, at the end of the 19th day at a dose of $2.5 \mathrm{mg} / \mathrm{mL}$, at the dose of $1.25 \mathrm{mg} / \mathrm{mL}$ and in the negative control group, all nematodes died at the end of the 20th day (Figure 3).

When the stem samples were examined, it was determined that all nematodes died at the end of the 10th day at a dose of $40 \mathrm{mg} / \mathrm{mL}$, at the end of the 12th day at a dose of $20 \mathrm{mg} / \mathrm{mL}$, and at the end of the 14th day at a dose of $10 \mathrm{mg} / \mathrm{mL}$. At the end of the $17 \mathrm{th}$ day at a dose of 5 $\mathrm{mg} / \mathrm{mL}$, at the end of the 19th day at a dose of $2.5 \mathrm{mg} / \mathrm{mL}$, at the dose of $1.25 \mathrm{mg} / \mathrm{mL}$ and in the negative control group, all nematodes were died at the end of the 20th day (Figure 4).

When the flower extract was examined, it was observed that all nematodes were died at the end of the 10th day at a dose of $40 \mathrm{mg} / \mathrm{mL}$, at the end of the 12th day at a dose of $20 \mathrm{mg} / \mathrm{mL}$, and at the end of the 14th day at a dose of 10 $\mathrm{mg} / \mathrm{mL}$. All nematodes died at the end of the 17 th day at a dose of $5 \mathrm{mg} / \mathrm{mL}$, at the end of the 19th day at a dose of 2.5 $\mathrm{mg} / \mathrm{mL}$, at the dose of $1.25 \mathrm{mg} / \mathrm{mL}$ and at the end of the 20th day in the negative control group (Figure 5).

According to the findings of leaf, stem, and flower extracts, the difference between negative control group and doses of $40 \mathrm{mg} / \mathrm{mL}$ and $20 \mathrm{mg} / \mathrm{mL}$ in all three groups, between doses of $2.5 \mathrm{mg} / \mathrm{mL}$ and $1.25 \mathrm{mg} / \mathrm{mL}$ with a dose of $40 \mathrm{mg} / \mathrm{mL}$ and $1.25 \mathrm{mg} / \mathrm{mL}$ with a dose of $20 \mathrm{mg} / \mathrm{mL}$ was statistically significant $(\mathrm{P}<0.05)$. When aerial part, leaf, stem, and flower groups are examined among themselves; only the difference between the aerial party and other groups was significant $(\mathrm{P}<0.05)$.

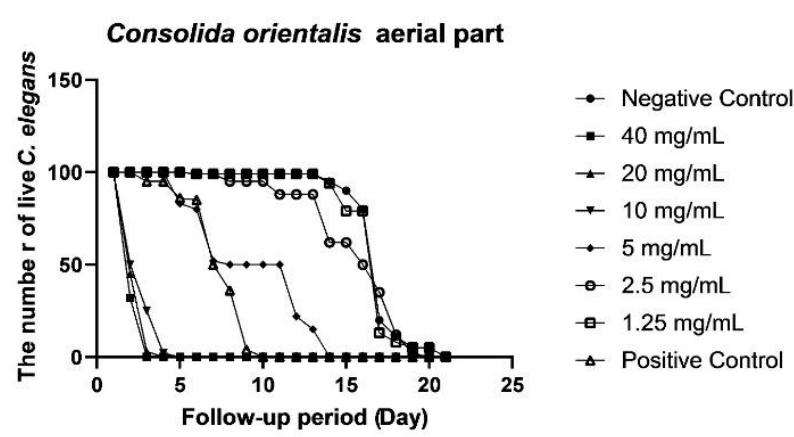

Figure 2. Graphic of the anti-helminthic effect of Consolida orientalis aerial part extract on C.elegans nematodes

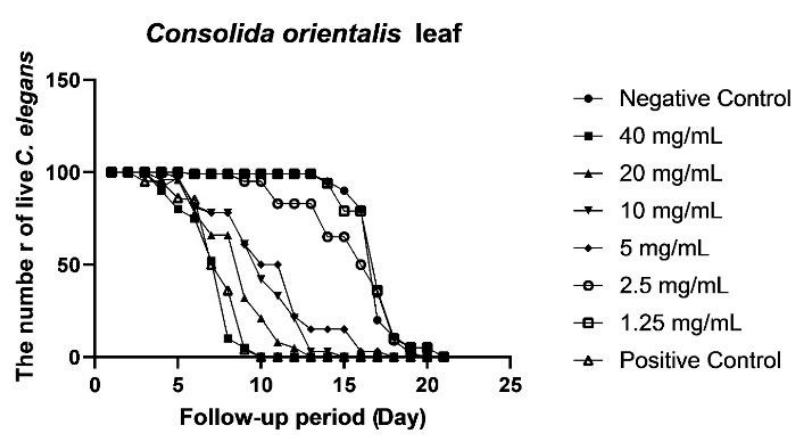

Figure 3. Graphic of the anti-helminthic effect of Consolida orientalis leaf extract on C.elegans nematodes

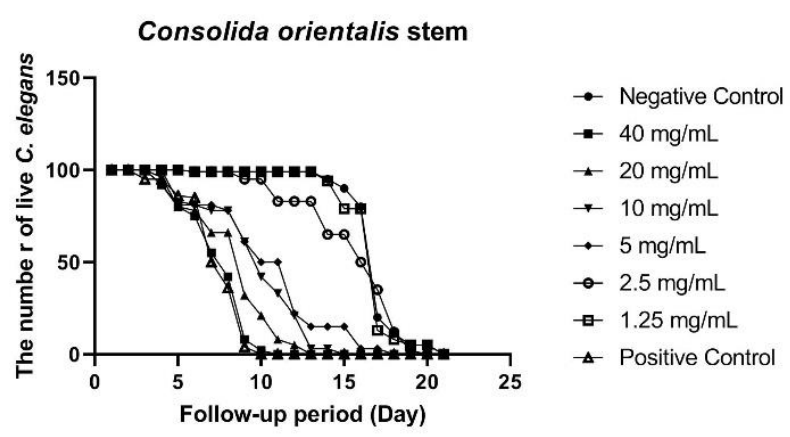

Figure 4. Graphic of the anti-helminthic effect of Consolida orientalis stem extract on C.elegans nematodes

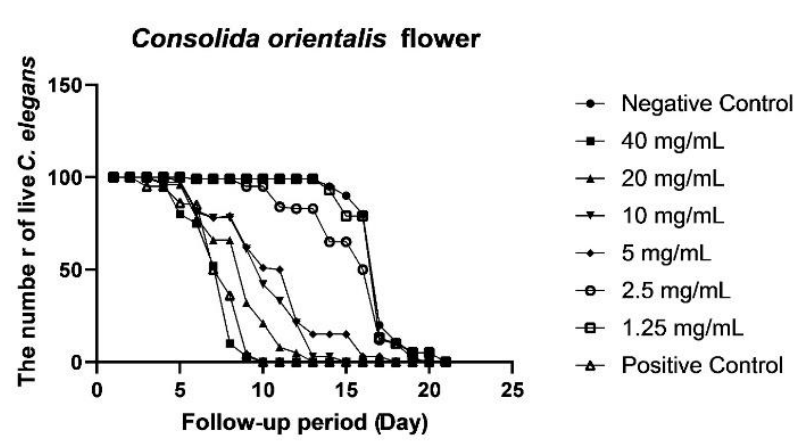

Figure 5. Graphic of the anti-helminthic effect of Consolida orientalis flower extract on C.elegans nematodes 
Table 1. Phytocomponents identified in the stem extract of $C$. orientalis by GC-MS

\begin{tabular}{l|cc}
\hline \multicolumn{1}{c|}{ Name of the Compound } & RT & Peak Area \% \\
\hline 1-Tridecene & 16.360 & 0.55 \\
1-Tetradecene & 16.360 & 0.55 \\
1-Dodecanethiol & 16.360 & 0.55 \\
1-Hexadecene & 22.643 & 0.44 \\
1-Pentadecene & 22.643 & 0.44 \\
2-Pentadecanone & 33.961 & 1.67 \\
Hexadecanoic acid & 36.971 & 1.26 \\
Eicosane & 42.395 & 0.44 \\
Methoxyacetic acid & 42.395 & 0.44 \\
Heneicosane & 42.395 & 0.44 \\
9-Octadecenamide & 43.465 & 34.65 \\
Eicosane & 45.737 & 0.69 \\
1-Bromoeicosane & 45.737 & 0.58 \\
1,4-Bis(trimethylsilyl)benzene & 49.016 & 0.35 \\
Methyltris(trimethylsiloxy)silane & 52.037 & 0.94 \\
Tetrasiloxane, decamethyl & 52.037 & 0.64 \\
Silyloxy(silyloxysilyloxy)silane & 55.934 & 0.72 \\
\hline
\end{tabular}

Table 2. Phytocomponents identified in the flower extract of $C$. orientalis by GC-MS

\begin{tabular}{|c|c|c|}
\hline Name of the Compound & RT & Peak Area \% \\
\hline 2(3H)-Benzoxazolone & 26.677 & 1.84 \\
\hline 2-Pentadecanone & 33.956 & 0.59 \\
\hline Lidocaine & 35.186 & 0.44 \\
\hline Hexadecanoic acid & 36.965 & 5.26 \\
\hline Ethyl tridecanoate & 36.965 & 5.26 \\
\hline Octacosane & 38.922 & 0.55 \\
\hline Heneicosane & 38.922 & 0.55 \\
\hline Hexatriacontane & 38.922 & 0.55 \\
\hline Linoleic acid & 41.881 & 1.08 \\
\hline Tricosane & 42.396 & 2.80 \\
\hline Hexacosane & 42.396 & 2.80 \\
\hline 9-Octadecenamide & 43.460 & 16.60 \\
\hline Eicosane & 45.732 & 2.51 \\
\hline Hexatriacontane & 45.732 & 2.51 \\
\hline Pentacosane & 45.732 & 2.51 \\
\hline Octadecane & 52.037 & 3.02 \\
\hline
\end{tabular}

Table 3. Phytocomponents identified in the aerial part extract of $C$. orientalis by GC-MS

\begin{tabular}{l|cc}
\multicolumn{1}{c|}{ Name of the Compound } & RT & Peak Area \% \\
\hline Octanal & 9.620 & 0.07 \\
Nonanal & 13.254 & 0.09 \\
1-Dodecene & 16.355 & 0.15 \\
Octanoic acid & 16.612 & 0.12 \\
1-Hexadecene & 22.632 & 0.12 \\
3-Octadecene & 22.632 & 0.21 \\
Nonanoic acid & 25.710 & 0.12 \\
Tetradecanoic acid & 32.863 & 0.48 \\
2-Pentadecanone & 33.956 & 0.17 \\
n-Hexadecanoic acid & 36.387 & 0.27 \\
9-Octadecenamide & 40.399 & 1.27 \\
Octadecanoic acid & 40.627 & 0.24 \\
Linoleic acid & 40.891 & 0.10 \\
Eicosadienoic acid & 40.999 & 0.45 \\
Tetracosenoic acid & 43.340 & 0.87 \\
Oleic Acid & 46.504 & 0.18 \\
Dihidrocarvone & 46.716 & 0.21 \\
Eicosane & 49.016 & 0.20 \\
2-Ethylacridine & 53.296 & \\
\hline
\end{tabular}


Table 4. Phytocomponents identified in the leaf extract of C. orientalis by GC-MS

\begin{tabular}{l|cc}
\hline \multicolumn{1}{c|}{ Name of the Compound } & RT & Peak Area \% \\
\hline Pentadecane & 2.725 & 6.48 \\
1-Undecanol & 16.355 & 0.67 \\
1-Tridecene & 16.355 & 0.67 \\
1-Hexadecene & 22.632 & 0.65 \\
Cyclododecane & 22.632 & 0.65 \\
Pentadecene & 22.632 & 0.65 \\
2(4H)-Benzofuranone & 26.425 & 0.53 \\
Loliolide & 32.336 & 1.04 \\
2-Pentadecanone & 33.956 & 6.30 \\
Hexadecanoic acid & 36.971 & 3.42 \\
9-Octadecenamide & 40.038 & 0.37 \\
Hexadecanamide & 40.381 & 1.04 \\
Tetradecanamide & 40.381 & 1.04 \\
1-octadecanol & 41.732 & 0.36 \\
2-methyltetracosane & 42.395 & 0.30 \\
Eicosane & 42.395 & 0.30 \\
Silane & 50.240 & 0.28 \\
\hline
\end{tabular}

Plant extracts compared to the pyrantel pamoate 5 $\mathrm{mg} / \mathrm{mL}$ used as positive control in the study, the difference in concentration of $2.5 \mathrm{mg} / \mathrm{mL}$ and $1.25 \mathrm{mg} / \mathrm{mL}$ with positive control of the leaf and stem extract of $C$. orientalis was found to be significant $(\mathrm{P}<0.05)$, while the difference between other concentrations was insignificant $(\mathrm{P}>0.05)$. While positive control in flower extract and a difference in concentration of $1.25 \mathrm{mg} / \mathrm{mL}$ were significant $(\mathrm{P}<0.05)$, the difference between it and other concentrations was insignificant $(\mathrm{P}>0.05)$.

As a result of the study, it was determined that the aerial part, leaf and stem extract of $C$. orientalis was more effective in the first four concentrations $(40 \mathrm{mg} / \mathrm{mL}, 20$ $\mathrm{mg} / \mathrm{mL}, 10 \mathrm{mg} / \mathrm{mL}, 5 \mathrm{mg} / \mathrm{mL}$ ) than pyrantel pamoate at a concentration of $5 \mathrm{mg} / \mathrm{mL}$ used in the study.

When GC-MS tables of plant extracts are examined, the substances commonly found in all four extracts of the leaves, flowers, stems and aerial parts; are 2Pentadecanone, Hexadecanoic acid, 9-Octadecenamide, and Eicosane (Table 1, 2, 3, 4). When the results of the flower extract were examined, substances known for their local analgesic, anti-arrhythmic, and anti-inflammatory effects (Ali and El-Mallakh, 2020) such as Lidocaine $(0.44 \%)$ were detected. Leaf extract has lolliolide $(1.04 \%)$, which can be found in many organisms with antiinflammatory, anti-tumor or anti-bacterial activities (Grabarczyk et al., 2015). Again, when the GC-MS results of the flower extract were examined, the compound $2(3 \mathrm{H})$ Benzoxazolone (1.84) was found. It was stated in the literature that the compounds with the derivatives of this compound also have biological activities such as analgesic and anti-inflammatory. When the extract of the aerial part was examined, the compound found in plants showing anthelmintic activity such as Dihidrocarvone $(0.18 \%)$ was detected (Jaiswal et al., 2011; Katiki et al., 2019).

\section{Discussion}

There are many studies in the literature on the anthelmintic activity of various plant extracts (Garbin et al., 2021; Lima et al., 2021). Ethnobotanical studies have shown that Consolida species are commonly used as anthelmintic plants in some countries such as Turkey and
China (Yin et al., 2020). In addition, the anthelmintic effect of ethanol extracts on Ascaris suum's eggs and infectious larvae of Trichostrongylus colubriformis was investigated in the Czech Republic of a total of 16 plants, including Consolida regalis. The research findings demonstrated that plants such as $C$. regalis ve $A$. sativum, A. absinthium, $C$. carvi, I. helenium, J. regia, S. hortensis, V. officinalis had a higher effect against infectious third-stage larvae compared to synthetic anthelmintic Zentel (albendazole) (Urban et al., 2008).

There has been no study in the literature that investigates the anthelmintic effect of the $C$. orientalis.

In our study, four different extracts (flowers, leaves, stems, and aerial parts) from $C$. orientalis also had an anthelmintic effect on $C$. elegans nematodes. The extract with the highest effect was found as aerial part extract. It is thought that the anthelmintic effect may be due to the "Dihydrocarvone" compound detected in GC-MS analyses and found in anthelmintic-acting plants (Jaiswal et al., 2011). It has also been found in the literature that substances derived from peroxidation of dihydrocarvone also shown anti-malarial activity (Dong et al., 2010). $C$. orientalis flowers were recorded as antiparasitic in a study the use of plants in folk medicine in Ilam province, Dehloran and Abdanan districts in Iran (Ghasemi et al., 2013). In addition, 2(3H)-Benzoxazolone compound was detected when the GC-MS results of the flower extract were examined. It is stated in the literature that the compounds with the derivatives of this compound have many biological activities such as analgesic (Zheng et al., 2015), anti-cancer (Erdag, 2020) and anti-inflammatory (Tang et al., 2021). Their activity is mostly determined by the type of the substituents on the fundamental heterocyclic structure. Halogen-substituted 2-benzoxazolones are known to have potent antibacterial and fungicidal effects. As a result, studying the biological characteristics of compounds with benzoxazolone or oxazolopyridinone rings may lead to the identification of novel members of this class (Courtois et al., 2004).

As a result of cytotoxicity studies, it has been shown that the flower and aerial part of $C$. orientalis have not shown any cytotoxic effect on the WI-38 human fibroblast cell line (Ozpinar, 2020). 


\section{Conclusion}

As a result of the study, it was determined that the aerial part, leaf, and stem extract of the first four concentrates (40 $\mathrm{mg} / \mathrm{mL}, 20 \mathrm{mg} / \mathrm{mL}, 10 \mathrm{mg} / \mathrm{mL}, 5 \mathrm{mg} / \mathrm{mL}$ ) of C. orientalis were more effective than pyrantel pamoate at a concentration of $5 \mathrm{mg} / \mathrm{mL}$. GS-MS results identified compounds with many biological activities. Dihidrocarvone, which is detected as a result of GC-MS, has been reported in the literature to have an anthelmintic effect. According to our study findings, chemotherapeutics such as Dihidrocarvone and $2(3 \mathrm{H})$-Benzoxazolone with new anthelmintic-antiparasitic activity are thought to contribute to further research.

\section{References}

Ali ZA, El-Mallakh RS. 2020. Nebulized lidocaine in COVID19, an hypothesis. Medical Hypotheses, 144: 109947.

Asha M, Prashanth D, Murali B, Padmaja R, Amit A. 2001. Anthelmintic activity of essential oil of Ocimum sanctum and eugenol. Fitoterapia, 72: 669-670.

Bethony J, Brooker S, Albonico M, Geiger SM, Loukas A, Diemert D, Hotez PJ. 2006. Soil-transmitted helminth infections: ascariasis, trichuriasis, and hookworm. The Lancet, 367: 1521-1532.

Courtois M, Mincheva Z, Andreu F, Rideau M, Viaud-Massuard MC. 2004. Synthesis and biological evaluation with plant cells of new fosmidomycin analogues containing a benzoxazolone or oxazolopyridinone ring. Journal of Enzyme Inhibition and Medicinal Chemistry, 19(6): 559-565.

Dong Y, McCullough KJ, Wittlin S, Chollet J, Vennerstrom JL. 2010. The structure and antimalarial activity of dispiro-1, 2 , 4, 5-tetraoxanes derived from (+)-dihydrocarvone. Bioorganic \& Medicinal Chemistry Letters, 20: 6359-6361.

Drake L, Bundy D. 2001. Multiple helminth infections in children: impact and control. Parasitology, 122: S73-S81.

Erdag E. 2020. Synthesis of Novel 2 (3H)-Benzoxazolone mannich bases as potential agents for future studies of cancer treatment. Journal of Pharmaceutical Research International, 23-30.

Garbin VP, Munguía B, Saldaña JC, Deschamps C, Cipriano RR, Molento MB. 2021. Chemical characterization and in vitro anthelmintic activity of Citrus bergamia Risso and Citrus X paradisii Macfad essential oil against Haemonchus contortus Kirby isolate. Acta Tropica, 217: 105869.

Gatti S, Lopes R, Cevini C, Ijaoba B, Bruno A, Bernuzzi A, De Lio P, Monco A, Scaglia M. 2000. Intestinal parasitic infections in an institution for the mentally retarded. Annals of Tropical Medicine \& Parasitology, 94: 453-460.

Ghanbarpour K, Tavassoli M, Shamsi L. 2019. Pesticide effects of Consolida orientalis extract on larval stage of Argas persicus (Acari: Argasidae). Persian Journal of Acarology 8.

Ghasemi PA, Momeni M, Bahmani M. 2013. Ethnobotanical study of medicinal plants used by Kurd tribe in Dehloran and Abdanan districts, Ilam province, Iran. African Journal of Traditional, Complementary and Alternative Medicines, 10: 368-385.

Grabarczyk M, Wińska K, Mączka W, Potaniec B, Anioł M. 2015. Loliolide-the most ubiquitous lactone. Folia Biologica et Oecologica, 11: 1-8.

Gul C, Nazligul Y. 2008. A currenta approach to helminthiasis. Dirim Medical Journal, 83: 40-48

Ibrahim A. 1992. Anthelmintic activity of some Sudanese medicinal plants. Phytotherapy Research, 6: 155-157.

Jaiswal V, Gupta S, Kumar A, Jafer S, Mittal S. 2011. Overview on medicinal plant used in anthelmintic. Drug Invention Today, 3 .
Kaminsky R, Ducray P, Jung M, Clover R, Rufener L, Bouvier J, Weber SS, Wenger A, Wieland-Berghausen S, Goebel T. 2008. A new class of anthelmintics effective against drugresistant nematodes. Nature, 452: 176.

Katiki L, Araujo R, Ziegelmeyer L, Gomes A, Gutmanis G, Rodrigues L, Bueno M, Verissimo C, Louvandini H, Ferreira J. 2019. Evaluation of encapsulated anethole and carvone in lambs artificially-and naturally-infected with Haemonchus contortus. Experimental Parasitology, 197: 36-42.

Lima AS, Junior HNPC, Costa-Junior LM, Monteiro OS, Maia JGS, da Rocha CQ. 2021. Anthelmintic effect of essential rhizome oil from Hedychium coronarium Koenig (Zingiberaceae) introduced in Northeastern Brazil. Acta Tropica, 218: 105912.

Marin C, Boutaleb-Charki S, Diaz JG, Huertas O, Rosales MJ, Pérez-Cordon G, Guitierrez-Sánchez R, Sánchez-Moreno M. 2009. Antileishmaniasis activity of flavonoids from Consolida oliveriana. Journal of Natural Products, 72: 10691074.

Marín C, Díaz JG, Maiques DI, Ramírez-Macías I, Rosales MJ, Guitierrez-Sánchez R, Cañas, R, Sánchez-Moreno M. 2017. Antitrypanosomatid activity of flavonoid glycosides isolated from Delphinium gracile, D. staphisagria, Consolida oliveriana and from Aconitum napellus subsp. Lusitanicum. Phytochemistry Letters, 19: 196-209.

Mathew MD, Mathew ND, Miller A, Simpson M, Au V, Garland S, Gestin M, Edgley ML, Flibotte S, Balgi A. 2016. Using $C$. elegans forward and reverse genetics to identify new compounds with anthelmintic activity. PLoS Neglected Tropical Diseases, 10: e0005058.

Ozpinar N. 2020. Amoebicidal activity of Consolida orientalis (Gay.) Schröd. on Acanthamoeba castellanii cysts and trophozoites and its cytotoxic potentials. International Journal of Academic Medicine and Pharmacy, 2: 34-39.

Ozcelik H, Korkmazturk M. 2013. Ranunculaceae family inventory of herbarium GUL. SDU Journal of Science, 8: 2247.

Ozpinar N. 2020. A model Organism for Antihelminthic Activity: Caenorhabditis elegans and Nigella sativa. Turkish Journal of Parasitology, 44, 31.

Smout MJ, Kotze AC, McCarthy JS, Loukas A. 2010. A novel high throughput assay for anthelmintic drug screening and resistance diagnosis by real-time monitoring of parasite motility. PLoS Neglected Tropical Diseases, 4: e885.

Tang L, Luo Jr, Wang Xy, Zhao B, Ge R, Liang Tg, Ban Sr, Li Qs. 2021. 4-Sulfonyloxy/alkoxy benzoxazolone derivatives with high anti-inflammatory activities: Synthesis, biological evaluation, and mechanims of action via p38/ERK-NF«B/iNOS pathway. Chemical Biology \& Drug Design, 97: 200-209.

Tappeh KH, Mohammadzadeh H, Rahim RN, Barazesh A, Khashaveh S, Taherkhani H. 2010. Prevalence of intestinal parasitic infections among mentally disabled children and adults of Urmia, Iran. Iranian Journal of Parasitology, 5: 60.

Tavassoli M, Maham M, Imani A, Rostami Z, Khezri A, Pourseyed S. 2012. Evaluation of Consolida orientalis and Adonis vernalis extracts on eggs and larval of Hyalomma anatolicum anatolicum and Rhipicephalus bursa. Journal of Medicinal Plants, 1: 141-148.

Urban J, Kokoska L, Langrova I, Matejkova J. 2008. In vitro anthelmintic effects of medicinal plants used in Czech Republic. Pharmaceutical Biology, 46: 808-813.

Yin T, Cai L, Ding Z. 2020. A systematic review on the chemical constituents of the genus Consolida (Ranunculaceae) and their biological activities. RSC Advances, 10: 35072-35089.

Zheng G, Chen T, Peng X, Long S. 2015. Synthesis, antiinflammatory, and analgesic activities of derivatives of 4Hydroxy-2-benzoxazolone. Journal of Chemistry, 2015. 